\title{
PENERAPAN METODE VAM DALAM OPTIMALKAN \\ BIAYA PENGIRIMAN SPARE PART PESAWAT \\ PADA PT. AVIASTAR MANDIRI
}

\author{
Andika Bayu Hasta Yanto \\ Sistem Informasi Kampus Jakarta \\ Fakultas Teknologi Informasi \\ Universitas Bina Sarana Informatika \\ andika.akx@bsi.ac.id
}

\begin{abstract}
Abstrak - Pengiriman yang sangat cepat, aman dan nyaman sangat berpengaruh untuk pelayanan sebuah perusahaan jasa. PT. Aviastar Mandiri salah satu perusahaan yang menyediakan pesawat sebagai alat transportasi ke daerah pelosok. PT. Aviastar Mandiri disini melakukan service rutin setiap bulan untuk maskapainya, demi keselamatan penerbangan. PT. Aviastar mengeluarkan anggaran sebesar Rp. 13.000.000,- untuk melakukan pengiriman spare part tersebut melalui maskapai lain. PT. Aviastar sangat memerlukan metode model transportasi pengiriman, sehingga dapat meminimalis pengeluaran. Metode yang digunakan adalah metode Vogel's Approximation Method (VAM). Optimasi anggaran biaya sebesar Rp. 610.650,- lebih sedikit dari anggaran biaya pengiriman spare part yang dikeluarkan perusahaan dengan cara biasa. Cara penyelesaian transportasi dengan menggunakan metode VAM yang di terapkan dalam aplikasi POM-QM For Windows version 3, sehingga menghasilkan biaya yang optimasi.
\end{abstract}

Kata kunci : Metode Vogel's Approximation Method (VAM), POM-QM For Windows Version 3.

\section{PENDAHULUAN}

Usaha dibidang penerbangan pada akhir-akhir periode ini semakin pesat berkembang, dengan pembangunan bandara-bandara baru dan rute-rute penerbangan baru juga. Terutama dalam era pesatnya pembangunan merata seluruh Indonesia akhir-akhir ini, banyak bandara yang dibuka, dengan tujuan untuk mempermudah pendistribusian sembako ke daerahdaerah belum terisolisir. Dan masih kurangnya pembangunan inprastruktur terutama jalan darat untuk mencapai pemukiman sampai pelosok-pelosok.

Transportasi udara adalah salah satu alternatif dalam mencapai daerah-daerah pelosok tersebut dalam pendistribusian sembako dengan waktu cepat dan aman. Dan PT. Aviastar Mandiri salah satu perusahaan penerbangan perintis yang melakukan hal tersebut. Dan perusahaan tersebut juga memerlukan biaya yang sangat besar. Baik dalam pembelian pesawat baru dan juga untuk perawatan alat transportasi tersebut, karena pesawat milik PT. Aviastar Mandiri tersebut ditempatkan dibandara daerah kecil. Salah satu yang dilakukan kantor pusat PT. Aviastar Mandiri yang berkantor pusat di Jakarta adalah pengiriman spare part
Abstract - Delivery is very fast, safe and comfortable very influential to service a service company. PT. Aviastar Mandiri one of the companies that provide aircraft to transport to remote areas. PT. Aviastar Mandiri here perform routine service every month for the airline, for the sake of flight safety. PT. Aviastar issued a budget of Rp. 13.000.000, - to carry out the delivery of spare parts through other airlines. PT. Aviastar is in need of transportation model method of delivery, so as to minimize expenses. The method used is the method of Vogel's Approximation Method (VAM). Optimization of the budget of Rp. 610 650, less than the cost of shipping the spare parts budget issued by the company in the normal way. Way of solving transportation using VAM methods were implemented in POM-QM application for windows version 3 , resulting in cost optimization.

Keyword : of Vogel's Approximation Method (VAM), POM-QM For Windows Version 3.

pesawat ke daerah-daerah dalam perawatan maskapainya.

Dan dalam hal pengiriman spare part tersebut, PT. Aviastar Mandiri bekerjasama dengan maskapai penerbangan yang bisa mengangkut cargo seperti : Garuda Indonesia, Lion Air dan Sriwijaya Air. Yang dimana kiriman spare part tersebut, akan diambil nanti oleh petugas PT. Aviastar Mandiri yang berada di daerah masing.

Transportasi bisa merupakan suatu proses penyaluran atau distribusi suatu barang ke beberapa atau berbagai daerah. Tingginya tingkat kebutuhan transportasi mengakibatkan kurangnya efisiensi kinerja dalam tujuan melayani masyarakat atau pelanggan. Sehingga diperlukan suatu metode transportasi yang dapat menyelesaikan serta mengoptimalkan kinerja transportasi dengan tujuan melakukan penghematan anggaran serta jarak

\section{METODE PENELITIAN}

\subsection{Tahapan Penelitian}

Tahapan penelitian kuantitatif dijelaskan secara umum sebagai berikut: 


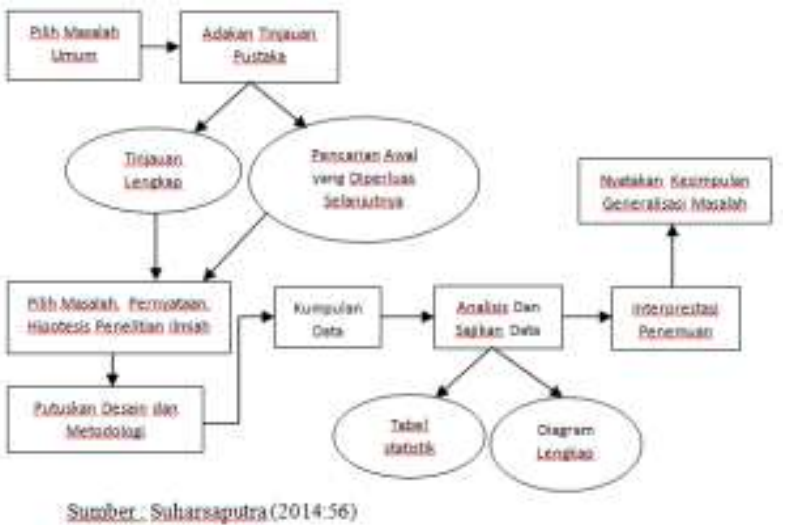

Gambar II.1. Tahapan/Proses Penelitian Kuantitatif

1. Menentukan masalah yang akan diteliti

Adapun masalah yang diangkat pada penelitian ini adalah :

a. Pengiriman spare part pesawat pada PT Aviastar Mandiri sering terjadi keterlambatan berakibat turunnya kualitas pelayanan.

b. Biaya pengiriman spare part yang tidak stabil berakibat kekalahan dalam bersaing dengan maskapai lain yang dapat mempengaruhi harga tiket.

c. Dikarenakan biaya pengiriman yang tidak menentu dapat berdampak pada pendapatan perusahaan.

2. Mengkaji teori/generalisasi empiris dan memilih proposisi yang berkaitan dengan masalal 17 kan diteliti

Mengambil refrensi dari buku-buku dan 3 jurnal yang berhubungan dengan materi yang akan diteliti. Refrensi tersebut dapat mendukung dalam pelaksanaan penelitian serta membantu dalam pembuatan laporan penelitian.

3. Menentukan konsep-konsep dan variabel-variabel

Konsep dari penelitian ini adalah mencari anggaran pengiriman spare part pesawat yang minimum. Sedangkan variabel dari penelitian ini adalah berbagai alat transportasi pengiriman spare part pesawat, berbagai rute tujuan pengiriman spare part pesawat, berat pengiriman spare part pesawat.

4. Menentukan desain penelitian serta hipotesis

Hipotesis dari penelitian ini sebagai berikut:

$\mathbf{H}_{\mathbf{0}}$ : Tidak ada hubungan antara rute pengiriman dengan biaya transportasi pengiriman spare part pesawat.

$\mathbf{H}_{1}$ : Ada hubungan antara rute pengiriman dengan biaya transportasi pengiriman spare part pesawat.

5. Menjabarkan konsep/variabel menjadi operasional Penulis menjabarkan variabel dari penelitian ini adalah berbagai alat transportasi pengiriman spare part pesawat, berbagai rute tujuan pengiriman spare part pesawat, berat pengiriman spare part pesawat.
6. Menentukan indikator-indikator konsep/variabel Berdasarkan variabel yang telah dijabarkan maka penulis dapat menentukan indikator-indikator variabel yaitu:

a. Alat transportasi pengiriman spare part pesawat: transportasi udara.

b. Rute tujuan pengiriman spare part pesawat: antar provinsi

c. Berat pengiriman spare part pesawat: paket dan ban pesawat.

7. Membuat instrumen penelitian

Setelah menentukan indikator variabel maka tahap selanjutnya penulis melakukan pengukuran terhadap indikator-indikator variabel berdasarkan bentuk pengukuran, yaitu pengukuran nominal, ordinal, rasio, dan interval.

8. Mengumpulkan data, menganalisis dan menyimpulkan

Pada tahap pengumpulan data penulis menggunakan tiga metode pengumpulan data, yaitu: observasi, wawancara, dan studi pustak

Setelah seluruh data terkun 18 ulis melakukan analisis data menggunakan ıne ude transportasi dengan metode pemecahan yang digunakan adalah metode Vogel's Approximation Method (VAM).

Kemudian penulis menyimpulkan hasil dari penelitian sehingga tergambar dengan jelas yang menjadi hasil penelitian.

9. Melaporkan

Tahap terakhir pada penelitian ini adalah penulis membuat sebuah laporan berdasarkan hasil penelitian ini berupa sebuah Skripsi.

\subsection{Instrumen Penelitian}

Setelah tahapan penelitian telah dirancang, maka langkah berikutnya penulis merancang instrumen penelitian. Jenis instrumen yang digunakan oleh penulis adalah intrumen wawancara. Dimana penulis melakukan wawancara dengan Bapak Rudi Siswanto pada Spv Aircraft Logistic di PT. Aviastar Mandiri guna mengumpulkan data-data yang dibutuhkan. Berikut ini instrumen penelitian yang penulis rancang :

Tabel III.1.

Operasionalisasi Konsep Biaya Pengiriman

\begin{tabular}{|c|c|c|c|}
\hline Variabel & Indikator & $\begin{array}{c}\text { Skala } \\
\text { Pengukur } \\
\text { an }\end{array}$ & $\begin{array}{l}\text { Pengukuran } \\
\text { Operasional }\end{array}$ \\
\hline $\begin{array}{l}\text { 1. } \\
\text { Alat } \\
\text { transpo } \\
\text { rtasi } \\
\text { pengiri } \\
\text { man } \\
\text { spare } \\
\text { part }\end{array}$ & $\begin{array}{l}\text { 1.1. Transport } \\
\text { asi udara } \\
\text { yaitu: } \\
\text { pesawat } \\
\text { cargo }\end{array}$ & $\begin{array}{l}\text { 1.1. Skala } \\
\text { nomi } \\
\text { nal }\end{array}$ & $\begin{array}{l}\text { 1.1. Wawanca } \\
\text { ra }\end{array}$ \\
\hline
\end{tabular}




\begin{tabular}{|c|c|c|c|c|}
\hline & $\begin{array}{l}\text { pesawa } \\
\text { t }\end{array}$ & & & \\
\hline 2. & $\begin{array}{l}\text { Rute } \\
\text { tujuan } \\
\text { pengiri } \\
\text { man } \\
\text { spare } \\
\text { part } \\
\text { pesawa } \\
\text { t }\end{array}$ & $\begin{array}{l}\text { 1.1. Antar } \\
\text { Provinsi } \\
\text { yaitu: } \\
\text { Jakarta- } \\
\text { Pontianak } \\
\text { Jakarta- } \\
\text { Balikpapa } \\
\text { n } \\
\text { Jakarta- } \\
\text { Makassar } \\
\text { Jakarta- } \\
\text { Ambon } \\
\text { Jakarta- } \\
\text { Jayapura }\end{array}$ & $\begin{array}{l}\text { 1.1. Skala } \\
\text { nomi } \\
\text { nal }\end{array}$ & $\begin{array}{l}\text { 1.1. Wawanca } \\
\text { ra }\end{array}$ \\
\hline 3. & $\begin{array}{l}\text { Bobot } \\
\text { pengiri } \\
\text { man } \\
\text { spare } \\
\text { part } \\
\text { pesawa } \\
\mathrm{t}\end{array}$ & $\begin{array}{l}\text { 1.1. Paket } \\
\text { yaitu: } 10 \\
\text { kg spare } \\
\text { part } \\
\text { pesawat } \\
\text { 1.2. Peti kayu } \\
\text { yaitu: } 20 \\
\text { kg Ban } \\
\text { pesawat }\end{array}$ & $\begin{array}{l}\text { 1.1. Skala } \\
\text { interv } \\
\text { al }\end{array}$ & $\begin{array}{l}\text { 1.1. Wawanca } \\
\text { ra }\end{array}$ \\
\hline
\end{tabular}

Sumber : Hasil Data Penelitian (2016), PT. Aviastar Mandiri

\subsection{Metode Pengumpulan Data, Populasi, dan Sampel Penelitian}

\subsubsection{Metode Pengumpulan Data}

Pada tahap pengumpulan data penulis menggunakan tiga metode pengumpulan data, yaitu:

1. Observasi

Penulis melakukan pengamatan dan penelitian secara langsung yakni dengan mengamati sistem pengiriman spare part pesawat yang diterapkan pada PT. Aviastar Mandiri guna memudahkan penulis untuk mendapatkan informasi yang dibutuhkan.

2. Wawancara

Penulis melakukan wawancara dengan Bapak Rudi Siswanto pada Spv Aircraft Logistic di PT. Aviastar Mandiri guna mengumpulkan bahan-bahan laporan yang berkaitan dengan sistem pengiriman spare part pesawat.

\section{Studi Pustaka}

Penulis mengambil beberapa referensi dari bukubuku dan jurnal-jurnal yang berkaitan dengan materi ini.

\subsubsection{Populasi}

Penulis menyimpulkan bahwa populasi dari penelitian ini adalah aircraft Logistic spare part pesawat PT. Aviastar Mandiri.

\subsubsection{Sampel}

Sedangkan sampel dari populasi tersebut adalah alat transportasi pengiriman spare part pesawat, rute pengiriman spare part pesawat, berat pengiriman spare part pesawat.

\subsection{Metode Analisis Data}

2.4.1. Model Transportasi

Model transportasi memecahkan masalah pendistribusian barang dari sumber ke tujuan dengan anggaran total distribusi minimum. Metode untuk memecahkan masalah transportasi pada penelitian ini, yaitu VAM atau Vogel's Approximation Method.

\subsubsection{Metode Vogel's Approximation Method (VAM)}

Pada analisis data penelitian ini penulis menggunakan metode vogel's approximation method (VAM) untuk pemecahan masalah transportasi dalam meminimumkan biaya transportasi pengiriman spare part pesawat.

Adapun langkah-langkah penggunaan metode vogel's approximation method (VAM) pada penelitian ini:

1. Menyusun kebutuhan, kapasitas masing-masing sumber dan anggaran pengangkutan ke dalam matriks.

2. Mencari perbedaan dari dua anggaran terkecil, yaitu anggaran terkecil dan terkecil kedua untuk tiap baris dan kolom pada matriks (Cij).

3. Memilih 1 nilai perbedaan-perbedaan yang terbesar diantara semua nilai perbedaan pada kolom dan baris.

4. Isikan pada salah satu segi empat yang termasuk dalam kolom atau baris terpilih, yaitu pada segi empat yang anggarannya terendah diantara segi empat lain pada kolom/baris tersebut. Isiannya sebanyak mungkin yang bisa dilakukan.

5. Hilangkan baris yang telah diisi sepenuhnya sehingga tidak mungkin untuk diisi lagi. Kemudian perhatikan kolom dan baris yang belum terisi/teralokasi.

6. Tentukan kembali perbedaan (selisih) anggaran pada langkah ke 2 untuk kolom dan baris yang belum terisi. Ulangi langkah 3 sampai 5, sampai semua baris dan kolom sepenuhnya teralokasi.

7. Setelah terisi semua, maka kalikan setiap kolom yang memiliki kapasitas serta jumlahkan seluruh kolom-kolom tersebut sehingga didapat anggaran transportasi yang harus dibayar.

8. Bila nilai perbedaan anggaran ada 2 yang besarnya sama, misal yang satu terletak di kolom, maka: Lihat segi empat yang masuk ke dalam kolom atau baris yang mempunyai nilai terbesar. Bila memiliki anggaran terendah maka isikan alokasi maksimum pada segi empat ini. Bila anggarannya tidak terendah maka pilih segi empat yang akan diisi berdasarkan salah satu, baris terpilih atau kolom terpilih.

\subsubsection{Aplikasi POM-QM For Windows 3}


Setelah mencari biaya transportasi pengiriman spare part pesawat yang minimum dengan menggunakan metode vogel's approximation method (VAM), maka penulis juga melakukan penerapan ke dalam aplikasi $P O M-Q M$ For Windows 3 .

\section{HASIL DAN PEMBAHASAN}

\subsection{Gambaran Umum Pengiriman Spare Part Pesawat Ke Sebagian Wilayah Indonesia Bagian Tengah dan Bagian Timur}

\subsubsection{Jenis Maskapai Penerbangan}

Berikut ini beberapa jenis Maskapai Penerbangan yang digunakan untuk pengiriman spare part pesawat ke wilayah Indonesia bagian Tengah dan Timur antara lain:

1. Garuda Indonesia Airlines

2. Lion Air

3. Sriwijaya Air

\subsubsection{Daerah Tujuan}

Pengiriman spare part pesawat ke sebagian wilayah Indonesia bagian Tengah dan Timur memiliki beberapa tujuan diantaranya :

1. Pontianak

Alamat : Bandara Supadio Pontianak - Kalimantan Barat

2. Balikpapan

Alamat : Bandara Sepinggan Balikpapan Kalimantan Timur

3. Makassar

Alamat : Bandara Hasanuddin Makassar Ujung Pandang - Sulawesi Selatan

4. Ambon

Alamat : Bandara Pattimura Ambon - Maluku

5. Jayapura

Alamat : Bandara Sentani Jayapura

\subsection{Supply Dan Demand Produk}

Adapun kapasitas supply masing-masing maskapai dan jumlah demand daerah tujuan antara lain :

1. Kapasitas supply dari masing-masing maskapai yaitu
a. Garuda Indonesia Airlines
$=250 \mathrm{Kg}$
b. Lion Air
$=250 \mathrm{Kg}$
c. Sriwijaya Air
$=250 \mathrm{Kg}$

2. Jumlah demand daerah tujuan yaitu :
a. Pontianak
$=150 \mathrm{Kg}$
b. Balikpapan
$=210 \mathrm{Kg}$
c. Makassar
$=225 \mathrm{Kg}$
d. Ambon
$=185 \mathrm{Kg}$
e. Jayapura
$=220 \mathrm{Kg}$

3.3. Gambaran Umum Transportasi Pengiriman 3.3.1. Jenis Transportasi
Pada pengiriman spare part pesawat ke sebagian wilayah Indonesia Bagian Tengah dan Bagian Timur, PT. Aviastar Mandiri menggunakan transportasi udara untuk jenis transportasinya.

\subsubsection{Anggaran Transportasi Pengiriman}

Adapun anggaran transportasi pengiriman spare part pesawat ke sebagian wilayah Indonesia Bagian Tengah dan Bagian Timur berdasarkan rute tujuan pengiriman adalah :

1. Garuda Indonesia Airlines
a. Jakarta - Pontianak
= Rp. 2.334.000,-
b. Jakarta - Balikpapan
= Rp. 3.330.600,-
c. Jakarta - Makassar
=Rp. 3.444.750,-
d. Jakarta - Ambon
$=$ Rp. 4.116.250,-
e. Jakarta - Jayapura
=Rp. 9.114.600,-

2. Lion Air
a. Jakarta - Pontianak
$=$ Rp. $\quad 2.235 .000,-$
b. Jakarta - Balikpapan
= Rp. 3.150.000,-
c. Jakarta - Makassar
= Rp. 3.307.500,-
d. Jakarta - Ambon
= Rp. 4.347.500,-
e. Jakarta - Jayapura
= Rp. 9.240.000,-

3. Sriwijaya Air
a. Jakarta - Pontianak
$=$ Rp. $\quad 2.250 .000,-$
b. Jakarta - Balikpapan
$=$ Rp. 3.360.000,-
c. Jakarta - Makassar
$=$ Rp. 3.262.500,-
d. Jakarta - Jayapura
$=$ Rp. 9.196.000,-

Jadi, anggaran transportasi per Kilogram adalah :

1. Maskapai Garuda Indonesia Airlines
a. Jakarta - Pontianak= Rp. $2.334 .000,-/ 150=$ Rp. 15.560.-/ Kg
b. Jakarta - Balikpapan= Rp. $3.330 .600,-/ 210=$ Rp. 15.860.-/ Kg
c. Jakarta - Makassar= Rp. 3.444.750,-/ $225=$ Rp. 15.310.-/ Kg
d. Jakarta - Ambon= Rp. $\quad 4.116 .250,-/ \quad 185=$ Rp. 22.250.-/ Kg
e. Jakarta - Jayapura $=$ Rp. $\quad 9.114 .600,-/ 220=$ Rp. 41.430.-/ Kg

2. Maskapai Lion Air
a. Jakarta - Pontianak= Rp. $\quad 2.325 .000,-/ 150=$ Rp. 15.500.-/ Kg
b. Jakarta - Balikpapan= Rp. $3.150 .000,-/ 210=$ Rp. 15.000.-/ Kg
c. Jakarta - Makassar= Rp. 3.307.500,-/ $225=$ Rp. 14.700.-/ Kg
d. Jakarta - Ambon= Rp. 4.347.500,-/ $185=$ Rp. 23.500.-/ Kg
e. $\quad$ Jakarta - Jayapura $=$ Rp. $\quad 9.240 .000,-/ 220=$ Rp. 42.000.-/ Kg 
3. Maskapai Sriwijaya Air

a. Jakarta - Pontianak= Rp. $2.250 .000,-/ 150=$ Rp. 15.000.-/ Kg

b. Jakarta - Balikpapan= Rp. $3.360 .000,-/ 210=$ Rp. 16.000.-/ Kg

c. Jakarta - Makassar= Rp. 3.262.500,-/ $225=$ Rp. 14.500.-/ Kg

d. Jakarta - Jayapura= Rp. $\quad 9.196 .000,-/ 220=$ Rp. 41.800.-/ Kg

Biaya transportasi selengkapnya dapat dilihat melalui tabel berikut :

Tabel IV.1.

Biaya Pengiriman Spare Part Pesawat

\begin{tabular}{|c|c|c|c|c|c|}
\hline R: & Pontianak & Balikpapan & $\begin{array}{l}\text { Ujung } \\
\text { Pandang }\end{array}$ & Amben & Jayapura \\
\hline $\begin{array}{c}\text { Garuda } \\
\text { indonesia }\end{array}$ & $\begin{array}{c}\mathrm{Rp} .15 .560 \\
,-i \mathrm{Kg}\end{array}$ & $\begin{array}{c}\mathrm{Rp} .15 .860 \\
--/ \mathrm{Kg}\end{array}$ & $\begin{array}{c}\text { Rp. } 15.310 \\
-\pi \mathrm{Kg}\end{array}$ & $\begin{array}{c}\text { Rp. } 22.250 \\
-1 K_{g}\end{array}$ & $\begin{array}{c}\mathrm{Rp}: 41.430 \\
--1 \mathrm{Kg}\end{array}$ \\
\hline Licen Air & $\begin{array}{c}\mathrm{Rp} . \\
-15.500 \\
-\mathrm{Kg}\end{array}$ & $\begin{array}{c}\text { Rp. } 15.000 \\
-\pi K g\end{array}$ & Rp. 14.700 & $\begin{array}{c}\mathrm{Rp} .23 .500 \\
\sim \mathrm{Kg}\end{array}$ & R.p. 42.000 \\
\hline $\begin{array}{c}\text { Sriwjaya } \\
\text { Ar }\end{array}$ & $\begin{array}{c}\mathrm{Rp}, 15,000 \\
\mathrm{~d} / \mathrm{Kg}\end{array}$ & $\begin{array}{c}\text { Rp. } 16.000 \\
-\sqrt{-} \mathrm{Kg}\end{array}$ & $\begin{array}{c}\text { Rp. } 14.500 \\
-\sqrt[K g]{ }\end{array}$ & - & $\begin{array}{c}\mathrm{Rp}, 41,800 \\
-2 \mathrm{Kg}\end{array}$ \\
\hline
\end{tabular}

Sumber : Hasil Data Penelitian (2016), PT. Aviastar Mandiri.

\subsection{Analisis Model Transportasi Pengiriman Spare Part Pesawat ke Sebagian Wilayah Indonesia Bagian Tengah dan Bagian Timur}

\subsubsection{Bentuk Analisis}

Bentuk Analisis yang digunakan dalam penulisan skripsi ini adalah dengan menggunakan metode Vogel's Approximation Method (VAM) dalam mencari anggaran pengiriman spare part pesawat yang paling optimal.

Dalam pengiriman spare part pesawat ke daerah tujuan, Bagian Pengadaan PT. Aviastar Mandiri menggunakan cara tersendiri. Adapun anggaran pengiriman transportasi spare part pesawat ke daerah wilayah Indonesia Tengah dan Timur yang digunakan oleh perusahaan sebesar Rp.13.000.000,- untuk kebutuhan perbaikan perbulannya.

\subsubsection{Analisis Menggunakan Metode Vogel's} Approximation Method (VAM)

1. Menyusun kebutuhan, kapasitas masing-masing sumber dan anggaran pengangkutan ke dalam matriks seperti tabel berikut :
Tabel IV.2.

Matriks biaya Pengiriman Spare Part Pesawat

\begin{tabular}{|c|c|c|c|c|c|c|}
\hline Rute & Pontianak & Balilpapan & $\begin{array}{c}\text { Ujung } \\
\text { Pandang }\end{array}$ & Ambon & Jayopure & Kapasitas \\
\hline $\begin{array}{c}\text { Garuda } \\
\text { Indonesia }\end{array}$ & $\begin{array}{r}15.560 \\
\times \quad 11 \\
\end{array}$ & $\begin{array}{r}15860 \\
\times 12 \\
\end{array}$ & $\begin{array}{r}15.310 \\
\times 13 \\
\end{array}$ & $\begin{array}{r}22.250 \\
\times \quad 4 \\
\end{array}$ & $\begin{array}{r}41.430 \\
\times 13 \\
\end{array}$ & 250 \\
\hline Lion Air & $\begin{array}{r}15.500 \\
\times 21 \\
\end{array}$ & $\begin{array}{r}15.000 \\
\times 22 \\
\end{array}$ & $\begin{array}{r}14.700 \\
\times 23 \\
\end{array}$ & $\begin{array}{r}23.500 \\
\times_{24} \\
\end{array}$ & $\begin{array}{r}42.000 \\
\times 25 \\
\end{array}$ & 250 \\
\hline $\begin{array}{c}\text { Srwijaya } \\
\text { A }_{i}\end{array}$ & $\begin{array}{r}15.000 \\
X_{31} \\
\end{array}$ & $\begin{array}{r}16.000 \\
\times \times 8 \\
\end{array}$ & $\begin{array}{r}14.500 \\
\times 33 \\
\end{array}$ & M & $\begin{array}{r}41.800 \\
\times 35 \\
\end{array}$ & 250 \\
\hline Pemintaan & 150 & 210 & 225 & 185 & 220 & 990 \\
\hline
\end{tabular}

Sumber : Hasil Data Penelitian (2016), PT. Aviastar Mandiri.

Karena ada beberapa pesawat yang memiliki keterbatasan tujuan/rute, maka $\mathrm{X}_{34}=\mathrm{M}$ (M adalah suatu bilangan positif sangat besar).

Dengan memerhatikan keadaan matriks di atas, maka dapat diketahui bahwa kapasitas angkutan pesawat (Supply) sebanyak $750 \mathrm{Kg}$ lebih kecil dibandingkan dengan jumlah permintaan (Demand) sebanyak $990 \mathrm{Kg}$. Hal ini disebut dengan model transportasi tidak seimbang. Agar model menjadi seimbang, perlu ditambahkan dengan baris dummy yang ditugaskan untuk meminta tambahan selisih antara kapasitas dan permintaan yaitu sebesar $240 \mathrm{Kg}$. Kapasitas tambahan sebanyak $240 \mathrm{Kg}$ tersebut tidak akan dikirim, melainkan akan dialokasikan ke sebuah sel dalam baris dummy. Anggaran transportasi sel-sel dalam baris dummy ini bernilai nol (0), karena jumlah yang dialokasikan ke dalam sel-sel tersebut bukan jumlah yang benar-benar dipindahkan tetapi jumlah yang kapasitas tidak terpenuhi. Penambahan sebuah baris atau kolom dummy ini tidak akan mempengaruhi metode untuk menentukan solusi optimal.

Tabel IV.3.

Penambahan Baris Dummy Pada Matriks

\begin{tabular}{|c|c|c|c|c|c|c|}
\hline 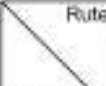 & Poentianak & Balkpapan & $\begin{array}{c}\text { Ulung } \\
\text { Pandang }\end{array}$ & Ambon & Jayapura & Kapasitas \\
\hline $\begin{array}{c}\text { Garuda } \\
\text { inocnesia }\end{array}$ & $\begin{array}{r}15.560 \\
\times 11 \\
\end{array}$ & $\begin{array}{r}15 \text { 860 } \\
\times 18 \\
\end{array}$ & $\begin{array}{r}15.310 \\
\times 13 \\
\end{array}$ & $\begin{array}{r}22.250 \\
\times 4 \\
\end{array}$ & $\begin{array}{r}41.430 \\
\times \quad 15 \\
\end{array}$ & 250 \\
\hline Uon Air & $\begin{array}{r}15.500 \\
\times 21 \\
\end{array}$ & $\begin{array}{r}15.000 \\
\times / 2 \\
\end{array}$ & $\begin{array}{r}14.700 \\
X_{2} \\
\end{array}$ & $\begin{array}{r}23.500 \\
\times 34 \\
\end{array}$ & $\begin{array}{r}42000 \\
\times 55 \\
\end{array}$ & 250 \\
\hline 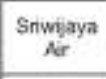 & $\begin{array}{l}15.000 \\
\times\end{array}$ & $\begin{array}{r}16.000 \\
\times \quad 2 \\
\end{array}$ & $\begin{array}{r}14500 \\
\times 33 \\
\end{array}$ & $M$ & $\begin{array}{r}41.800 \\
\times \quad \\
\end{array}$ & 250 \\
\hline Dumury & 0 & 0 & $X_{13}$ & $X_{\text {ua }}$ & $X_{15}$ & 240 \\
\hline mintaar & 150 & 210 & 225 & 185 & 220 & 990 \\
\hline
\end{tabular}

Sumber : Hasil Data Penelitian (2016), PT. Aviastar Mandiri.

2. Mencari perbedaan dari dua biaya terkecil, yaitu biaya terkecil dan terkecil kedua untuk tiap baris dan kolom pada matriks.

Baris Garuda Indonesia $=15.560-15.310=250$ 
Baris Lion Air $=15.000-14.700$

Baris Sriwijaya Air $=15.000-14.500$

$=300$

Baris Dummy $=0 \quad-0$

$=500$

$=0$

Kolom Pontianak $=15.000-0$

$=15.000$

$=15.000$

$\begin{aligned} \text { Kolom Ujungpandang } & =14.500-0 & =14.500 \\ \text { Kolom Ambon } & =22.250-0 & =22.250\end{aligned}$

Kolom Jayapura $\quad=41.430-0=41.430$

3. Memilih 1 nilai perbedaan-perbedaan yang terbesar diantara semua nilai perbedaan pada kolom dan baris.

Kolom Jayapura memiliki nilai perbedaan terbesar yaitu 41.430.

4. Isikan pada salah satu segi empat yang termasuk dalam kolom atau baris terpilih, yaitu pada segi empat yang anggarannya terendah diantara segi empat lain pada kolom/baris tersebut. Isiannya sebanyak mungkin yang bisa dilakukan.

Tabel IV.4.

Matriks Transportasi Iterasi 1

\begin{tabular}{|c|c|c|c|c|c|c|c|}
\hline Ruso & Perctanis & Ealkpear & $\begin{array}{l}\text { Lfong } \\
\text { Pandary }\end{array}$ & Amben & isersporas & Knoastas & $\begin{array}{c}\text { Prebectam } \\
\text { Borts }\end{array}$ \\
\hline 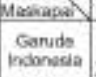 & $\begin{array}{l}15580 \\
X=\end{array}$ & $\begin{array}{l}15.860 \\
x_{11}\end{array}$ & $x: 2.15 .310$ & $\begin{array}{r}22.250 \\
x+4\end{array}$ & $\begin{array}{l}41.430 \\
x: 8\end{array}$ & 260 & 250 \\
\hline $\operatorname{Linn} A_{j}=$ & $\begin{array}{l}15.500 \\
X^{15}\end{array}$ & $\begin{array}{r}15.000 \\
\times 23 \\
\end{array}$ & $x^{16700}$ & \begin{tabular}{|c|}
${ }^{23500}$ \\
$x_{34}$
\end{tabular} & $\begin{array}{l}42000 \\
X^{4}\end{array}$ & 250 & 300 \\
\hline $\begin{array}{c}\text { Sitwisare } \\
\text { Air }\end{array}$ & $\begin{array}{r}15600 \\
\times 11 \\
\end{array}$ & $\begin{array}{l}16.000 \\
x=3\end{array}$ & $x={ }^{14.500}$ & M & \begin{tabular}{|l}
41.960 \\
$\times a$
\end{tabular} & 260 & 100 \\
\hline Oursiny & $x_{1}$ & $x_{12}$ & $x_{4}=$ & $x_{u}$ & $x_{10}$ & 206 & 0 \\
\hline Puncintain & 150 & 210 & 225 & 2as & 20 & \multirow{2}{*}{\multicolumn{2}{|c|}{$\begin{array}{l}\text { Pllihan } X_{45}=220 \\
\text { Hilangkan bolom } \\
\text { Jaysoura }\end{array}$}} \\
\hline $\begin{array}{c}\text { Pertedsan } \\
\text { Kolom }\end{array}$ & 15006 & 15000 & 14.50 & 2250 & 41,30 & & \\
\hline
\end{tabular}

Mandiri.

Sumber : Hasil Data Penelitian (2016), PT. Aviastar

5. Hilangkan kolom yang telah diisi sepenuhnya sehingga tidak mungkin untuk diisi lagi. Kemudian perhatikan kolom dan baris yang belum terisi/teralokasi.
Tabel IV.5.

Matriks Transportasi Hasil Iterasi 1

\begin{tabular}{|c|c|c|c|c|c|c|}
\hline skand $)$ & Portionak & Ballopapan & $\begin{array}{l}\text { Yyung } \\
\text { Pardang }\end{array}$ & Ant & $x$ & $\begin{array}{c}\text { Pertedas } \\
\text { Baris }\end{array}$ \\
\hline $\begin{array}{c}\text { Garuda } \\
\text { indonoala }\end{array}$ & $\begin{array}{r}16.600 \\
\times 11 \\
\end{array}$ & $\begin{array}{r}15800 \\
\times 18 \\
\end{array}$ & $\begin{array}{r}15.310 \\
X 15 \\
\end{array}$ & $\begin{array}{r}2 i \\
\times 4 \\
\end{array}$ & $\cos$ & 250 \\
\hline Liandir & $\begin{array}{r}15.500 \\
\times \quad \\
\end{array}$ & $\begin{array}{r}15.000 \\
\times 2 \\
\end{array}$ & $\begin{array}{r}14.700 \\
X_{3} \\
\end{array}$ & $\begin{array}{r}23.500 \\
X=4\end{array}$ & 250 & 300 \\
\hline$\underset{\text { Nir }}{\operatorname{aingaya}}$ & $\begin{array}{r}15.000 \\
X_{31}\end{array}$ & $\begin{array}{r}16000 \\
\times \quad \\
\end{array}$ & $\begin{array}{r}14.500 \\
\times 44\end{array}$ & M & 250 & 500 \\
\hline Oumany & $X_{+1} \quad 0$ & $\begin{array}{ll}0 & 0 \\
x_{12} & \\
\end{array}$ & $X_{42}$ & $x_{14}$ & 20 & 0 \\
\hline Pormivtas & 150 & 210 & 225 & $\mathrm{tas}$ & & \\
\hline $\begin{array}{l}\text { Perbedian } \\
\text { Kolcm }\end{array}$ & 15000 & $15 . \mathrm{nno}$ & 14,500 & 22.250 & & \\
\hline
\end{tabular}

Sumber : Hasil Data Penelitian (2016), PT. Aviastar Mandiri.

6. Tentukan kembali perbedaan (selisih) biaya pada langkah ke 2 untuk kolom dan baris yang belum terisi. Ulangi langkah 3 sampai 5, sampai semua baris dan kolom sepenuhnya teralokasi.

7. Pada iterasi 2 nilai perbedaan terbesar terdapat di Kolom Ambon, maka segi empat yang biayanya terendah adalah $\mathrm{X}_{44}$, jadi akan diisikan sebanyak mungkin sebesar 20, sehingga baris dummy terisi penuh dan dihilangkan.

Tabel IV.6.

Matriks Transportasi Iterasi 2

\begin{tabular}{|c|c|c|c|c|c|c|}
\hline Ruke & Ponfanak & Batikaapan & $\begin{array}{l}\text { Yisug } \\
\text { Pardang }\end{array}$ & Ambion & Kapasitas & $\begin{array}{c}\text { Perbedaan } \\
\text { Baris }\end{array}$ \\
\hline $\begin{array}{c}\text { Canuda } \\
\text { hudoriasia }\end{array}$ & $\begin{array}{r}15.560 \\
\times 11 \\
\end{array}$ & $\begin{array}{r}15860 \\
\times 12 \\
\end{array}$ & $\begin{array}{r}15.310 \\
\times 13 \\
\end{array}$ & $\begin{array}{r}22.250 \\
X_{14} \\
\end{array}$ & 250 & 250 \\
\hline Lion Air & $\begin{array}{r}15.500 \\
\times 21 \\
\end{array}$ & $\begin{array}{r}15.000 \\
\times \quad 2 \\
\end{array}$ & $\begin{array}{r}14.700 \\
\times 23 \\
\end{array}$ & $\begin{array}{r}23.500 \\
\times 44 \\
\end{array}$ & 250 & 300 \\
\hline $\begin{array}{c}\text { Sinwingya } \\
\text { Air }\end{array}$ & $\begin{array}{r}15.000 \\
\times \quad \\
\end{array}$ & $\begin{array}{r}16.000 \\
\times 0 \\
\end{array}$ & $\begin{array}{r}14.500 \\
X 13 \\
\end{array}$ & M & 250 & 500 \\
\hline Dummy & $X_{* 1} \quad 0$ & $x_{a}$ & $x_{01}$ & $x_{14}$ & 20 & 0 \\
\hline Permintsan & 150 & 210 & 225 & $\begin{array}{l}126 \\
165\end{array}$ & \multirow{2}{*}{\multicolumn{2}{|c|}{$\begin{array}{l}\text { Paidhan } X_{\triangle 4}=20 \\
\text { Hillangkaan Baris } \\
\text { Dummyy }\end{array}$}} \\
\hline $\begin{array}{c}\text { Pertuedasen } \\
\text { Kolon }\end{array}$ & 15.000 & 15.000 & 14.500 & 22.250 & & \\
\hline
\end{tabular}

Sumber : Hasil Data Penelitian (2016), PT. Aviastar Mandiri.

8. Pada iterasi 3 nilai perbedaan terbesar terdapat di Kolom Ambon, maka segi empat yang biayanya terendah adalah $\mathrm{X}_{14}$, jadi akan diisikan sebanyak mungkin sebesar 165, sehingga kolom Ambon terisi penuh dan dihilangkan. 
Tabel IV.7.

Matriks Transportasi Iterasi 3

\begin{tabular}{|c|c|c|c|c|c|c|}
\hline Futtr & Pensangk & Balikpopan & $\begin{array}{c}\text { Ujung } \\
\text { Pondang }\end{array}$ & Ambon & Kapasitas & $\begin{array}{c}\text { Perbedasan } \\
\text { Baris }\end{array}$ \\
\hline $\begin{array}{c}\text { Ganuda } \\
\text { Indonesia }\end{array}$ & $\begin{array}{r}15.560 \\
\times \quad \\
\end{array}$ & $\begin{array}{r}15.800 \\
x+2\end{array}$ & $\begin{array}{r}15.310 \\
\times 13\end{array}$ & $\begin{array}{r}22.250 \\
x_{4}\end{array}$ & 38 & 250 \\
\hline Lim Air & $\begin{array}{r}15500 \\
\times \quad \\
\end{array}$ & $\begin{array}{r}15000 \\
x_{32} \\
\end{array}$ & $\begin{array}{r}14.700 \\
\times 23 \\
\end{array}$ & $\begin{array}{r}23.500 \\
\times 24 \\
\end{array}$ & 280 & 300 \\
\hline$\underset{\text { Air }}{\text { Snupre }}$ & $\begin{array}{r}15.000 \\
x_{31}\end{array}$ & $\begin{array}{r}15.000 \\
\times 00\end{array}$ & $\begin{array}{r}14500 \\
\times 00 \\
\end{array}$ & M & 250 & 500 \\
\hline Pectrintaar & 160 & 210 & 225 & 108 & \multirow{2}{*}{\multicolumn{2}{|c|}{$\begin{array}{l}\text { Pilihan X14 } X_{165} 165 \\
\text { Hilangikan Kolom } \\
\text { Ambion }\end{array}$}} \\
\hline $\begin{array}{l}\text { Perbedisan } \\
\text { Kolam }\end{array}$ & 500 & 860 & 200 & 1250 & & \\
\hline
\end{tabular}

Sumber : Hasil Data Penelitian (2016), PT. Aviastar Mandiri.

9. Pada iterasi 4 nilai perbedaan terbesar terdapat di Kolom Balikpapan, maka segi empat yang biayanya terendah adalah $\mathrm{X}_{22}$, jadi akan diisikan sebanyak mungkin sebesar 210, sehingga kolom Balikpapan terisi penuh dan dihilangkan.

Tabel IV.8.

Matriks Transportasi Iterasi 4

\begin{tabular}{|c|c|c|c|c|c|}
\hline Rute & Pontianak & Balkpapan & $\begin{array}{c}\text { Ujung } \\
\text { Pandang }\end{array}$ & Kepasitas & $\begin{array}{c}\text { Perbedaan } \\
\text { Baris }\end{array}$ \\
\hline $\begin{array}{l}\text { Ganuda } \\
\text { Indonesia }\end{array}$ & $\begin{array}{r}15.560 \\
\times 11 \\
\end{array}$ & $\begin{array}{r}15.860 \\
\times 12 \\
\end{array}$ & $\begin{array}{r}15.310 \\
X .3\end{array}$ & 85 & 250 \\
\hline Lion Air & $\begin{array}{r}15.500 \\
\times 21\end{array}$ & $\begin{array}{r}15.000 \\
\times \quad 2\end{array}$ & $\begin{array}{r}14700 \\
\times \quad 3\end{array}$ & 280 & 300 \\
\hline $\begin{array}{c}\text { Snwiaya } \\
\text { Air }\end{array}$ & $\begin{array}{r}15.000 \\
X_{31}\end{array}$ & $\begin{array}{r}16,000 \\
\times \quad 2\end{array}$ & $\begin{array}{r}14.500 \\
\times 13\end{array}$ & 250 & 500 \\
\hline Pemintaan & 150 & & 225 & \multirow{2}{*}{\multicolumn{2}{|c|}{$\begin{array}{l}\text { Pilihan } X_{2 i}=210 \\
\text { Hilangican Kolom } \\
\text { Balikpapan }\end{array}$}} \\
\hline $\begin{array}{c}\text { Perbedaan } \\
\text { Kolom }\end{array}$ & 500 & 860 & 200 & & \\
\hline
\end{tabular}

Sumber : Hasil Data Penelitian (2016), PT. Aviastar Mandiri.

10. Pada iterasi 5 nilai perbedaan terbesar terdapat di Baris Lion AIR, maka segi empat yang biayanya terendah adalah $\mathrm{X}_{23}$, jadi akan diisikan sebanyak mungkin sebesar 40, sehingga BARIS LION AIR terisi penuh dan dihilangkan.
Tabel IV.9.

Matriks Transportasi Iterasi 5

\begin{tabular}{|c|c|c|c|c|}
\hline Rute & Pontianak & $\begin{array}{c}\text { Ujung } \\
\text { Pandang }\end{array}$ & Kapasitas & $\begin{array}{c}\text { Perbedaan } \\
\text { Baris }\end{array}$ \\
\hline $\begin{array}{c}\text { Ganida } \\
\text { Indonesia }\end{array}$ & $\begin{array}{r}15.560 \\
\times_{11} \\
\end{array}$ & $\begin{array}{r}15.310 \\
\times 13 \\
\end{array}$ & 85 & 250 \\
\hline Lion Air & $\begin{array}{r}15.500 \\
\times 21 \\
\end{array}$ & $\begin{array}{r}14.700 \\
\times 23 \\
\end{array}$ & & 800 \\
\hline $\begin{array}{l}\text { Sriwijaya } \\
\text { Air }\end{array}$ & $\begin{array}{r}15,000 \\
\times 31\end{array}$ & $\begin{array}{r}14.500 \\
X_{33}\end{array}$ & 34 & 500 \\
\hline Permintaan & 150 & $\begin{array}{l}225 \\
185 \\
\end{array}$ & \multirow{2}{*}{\multicolumn{2}{|c|}{$\begin{array}{l}\text { Hilangkan Baris } \\
\text { Lion Air }\end{array}$}} \\
\hline $\begin{array}{c}\text { Perbedaan } \\
\text { Kolom }\end{array}$ & 500 & 200 & & \\
\hline
\end{tabular}

Sumber : Hasil Data Penelitian (2016), PT. Aviastar Mandiri.

11. Pada iterasi 6 nilai perbedaan terbesar terdapat di Baris Lion AIR, maka segi empat yang biayanya terendah adalah $\mathrm{X}_{33}$, jadi akan diisikan sebanyak mungkin sebesar 185, sehingga kolom ujungpandang terisi penuh dan dihilangkan.

Tabel IV.10

Matriks Transportasi Iterasi 6

\begin{tabular}{|c|c|c|c|c|}
\hline Rute & Pontianak & $\begin{array}{l}\text { Ujung } \\
\text { Pandang }\end{array}$ & Kapasitas & $\begin{array}{c}\text { Perbedaan } \\
\text { Baris }\end{array}$ \\
\hline $\begin{array}{c}\text { Ganuda } \\
\text { Indonesia }\end{array}$ & $\begin{array}{r}15,560 \\
\times 11 \\
\end{array}$ & $\begin{array}{r}15.310 \\
\times 13 \\
\end{array}$ & 85 & 250 \\
\hline $\begin{array}{c}\text { Sriwijaya } \\
\text { Air }\end{array}$ & $\begin{array}{r}15.000 \\
\times 31 \\
\end{array}$ & $\begin{array}{r}14.500 \\
\times 33\end{array}$ & 65 & 500 \\
\hline Pemintaan & 150 & & \multirow{2}{*}{\multicolumn{2}{|c|}{$\begin{array}{l}\text { Pilihan } X_{33}=185 \\
\text { Hilangkan kolom } \\
\text { Ujungpandang }\end{array}$}} \\
\hline $\begin{array}{c}\text { Perbedaan } \\
\text { Kolom }\end{array}$ & 560 & 810 & & \\
\hline
\end{tabular}

Sumber : Hasil Data Penelitian (2016), PT. Aviastar Mandiri.

12. Pada iterasi 7 nilai perbedaan terbesar terdapat di Baris Lion AIR, maka segi empat yang biayanya terendah adalah $\mathrm{X}_{33}$, jadi akan diisikan sebanyak mungkin sebesar 185, sehingga kolom ujungpandang terisi penuh dan dihilangkan. 
Tabel IV.11.

Matriks Transportasi Iterasi 7

\begin{tabular}{|c|c|c|c|}
\hline Rute & Pontianak & Kapasitas & $\begin{array}{c}\text { Perbedaan } \\
\text { Baris }\end{array}$ \\
\hline $\begin{array}{c}\text { Garuda } \\
\text { Indonesia }\end{array}$ & $\begin{array}{r}15.560 \\
\times 11 \\
\end{array}$ & 85 & 15.560 \\
\hline $\begin{array}{c}\text { Sriwjiaya } \\
\text { Air }\end{array}$ & $\begin{array}{r}15.000 \\
X_{31}\end{array}$ & 65 & 15.000 \\
\hline Permintaan & 150 & \multirow{2}{*}{\multicolumn{2}{|c|}{$\begin{array}{l}\text { Pilihan } X_{11}=85 \\
\text { Pilihan } X_{31}=65\end{array}$}} \\
\hline $\begin{array}{c}\text { Perbedaan } \\
\text { Kolom }\end{array}$ & 560 & & \\
\hline
\end{tabular}

Sumber : Hasil Data Penelitian (2016), PT. Aviastar Mandiri.

Jadi matriks alokasi dengan metode Vogel's Approximation Method seperti tabel berikut :

Tabel IV.12.

Hasil Pengalokasian Dengan Metode VAM

\begin{tabular}{|c|c|c|c|c|c|c|}
\hline ante & Pontanak & Balikpapan & $\begin{array}{c}\text { Ujung } \\
\text { Pandang }\end{array}$ & Ambon & Jayapura & Kapasitas \\
\hline $\begin{array}{c}\text { Garuda } \\
\text { Indonesia }\end{array}$ & $85^{15.560}$ & $\begin{array}{l}15.860 \\
\mathbf{X}_{12}\end{array}$ & $\begin{array}{r}15.310 \\
X: 3\end{array}$ & $\begin{array}{c}22.250 \\
165^{250}\end{array}$ & $\begin{array}{r}41.430 \\
\times 15\end{array}$ & 250 \\
\hline Lion Air & $\begin{array}{r}15.500 \\
X_{21}\end{array}$ & $\begin{array}{c}15.000 \\
210^{-1}\end{array}$ & $40^{14.700}$ & $x^{23.500}$ & $\begin{array}{l}42.000 \\
X_{25}\end{array}$ & 250 \\
\hline$\underset{\text { Air }}{\text { Stwaya }}$ & $65^{15.000}$ & $\mathrm{X}^{160}{ }^{16.000}$ & $15^{14,500}$ & $M$ & $X^{45}{ }^{41.800}$ & 250 \\
\hline Dumuny & $X_{a 1}$ & $x_{12}$ & $X_{\text {aa }}$ & 20 & 220 & 240 \\
\hline Permintasen & 150 & 210 & 225 & 185 & 220 & $\$ 90$ \\
\hline
\end{tabular}

Sumber : Hasil Data Penelitian (2016), PT. Aviastar Mandiri.

13. Setelah terisi semua, maka kalikan setiap kolom yang memiliki kapasitas serta jumlahkan seluruh kolom-kolom tersebut sehingga didapat biaya transportasi yang harus dibayar.

Biaya Transportasi $=85(15.560)+165(22.250)$ $+210(15.000)+40(14.700)+65(15.000)+185$ $(14.500)+20(0)+220(0)=1.322 .600+3.671 .250+$ $3.150 .000+588.000+975.000+2.682 .500+0+0$

$$
\equiv \mathbf{1 2 . 3 8 9 . 3 5 0}
$$

Jadi, total biaya transportasi untuk pengiriman spare part pesawat ke daerah tujuan yang optimal sebesar Rp. 12.389.350,-.

Berdasarkan hasil penelitian metode transportasi pengiriman dengan menggunakan Vogel's
Approximation Method (VAM), maka diperoleh hasil efisiensi biaya transportasi pengiriman sebesar :

Rp. 13.000.000 - Rp. 12.389.350 = Rp. 610.650,- $/$ Bulan

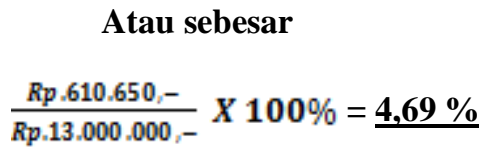

\subsection{Penerapan Aplikasi POM-QM For Windows 3}

1. Jalankan Aplikasi POM-QM For Windows 3.

2. Arahkan ke menu module, lalu pilih program Transportation.

3. Pada menu utama pilih File kemudian New.

4. Klik pada bagian Title 〈untitled> dengan disikan "Pengiriman Spare Part Pesawat ke sebagian daerah Indonesia Bagian Tengah dan Bagian Timur".

5. Isi jumlah sumber pada number of sources dan tujuan pada number of destination dengan cara mengetik langsung pada angka yang ada atau dengan mengeklik/menggerakkan tanda panah, pada number of sources disikan 4 karena 3 baris Makapai dan 1 baris dummy dan pada number of destination diisikan 5 karena 5 kolom tujuan.

6. Pada objective dipilih sesuai fungsi tujuan, dalam permasalahan ini fungsi tujuannya adalah meminimalkan biaya, berarti kita pilih minimize.

7. Langkah selanjutnya pada Row names, klik Other, ketikkan: Bus dan pada Column names, klik Other, ketikkan: Tujuan. Tekan OK.

8. Isi tabel pada tampilan tersebut sesuai permasalahan, bisa diubah sesuai nama tujuan dan sumber serta kapasitasnya dengan cara mengetik seperti biasa. Besarnya biaya pengangkutan juga dimasukkan berdasarkan permasalahannya sehingga hasilnya adalah sebagai berikut:

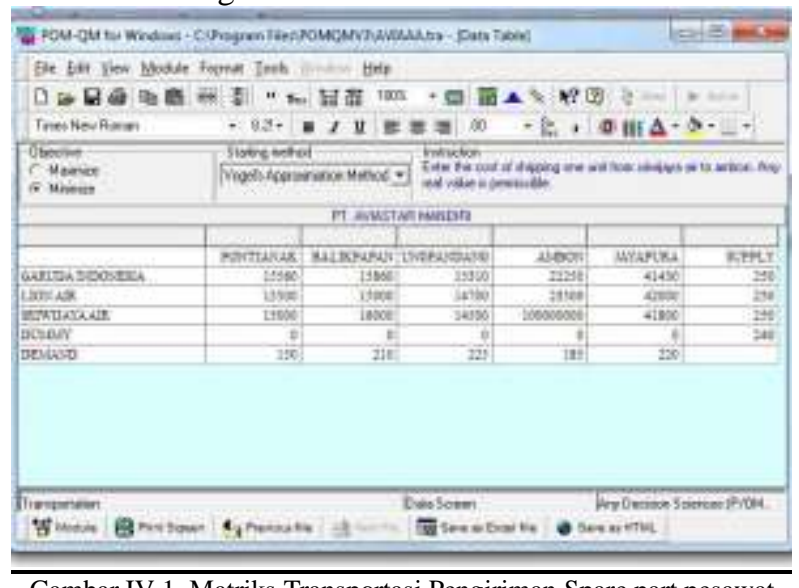

Gambar IV.1. Matriks Transportasi Pengiriman Spare part pesawat

9. Klik starting method (pada tanda panah) untuk memilih metode yang akan digunakan dalam analisis ini adalah metode Vogel's Approximation Method. 
10. Pilih/klik Solve, untuk menampilkan hasil analisis hingga muncul tampilan output, maka solusi permasalahan transportasinya adalah sebagai berikut:

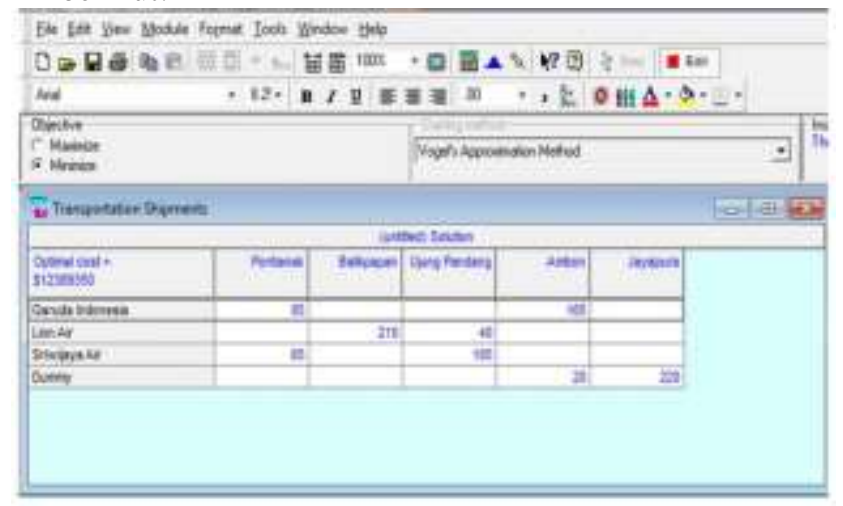

Gambar IV. 2 Hasil Pengalokasian Dengan Metode VAM

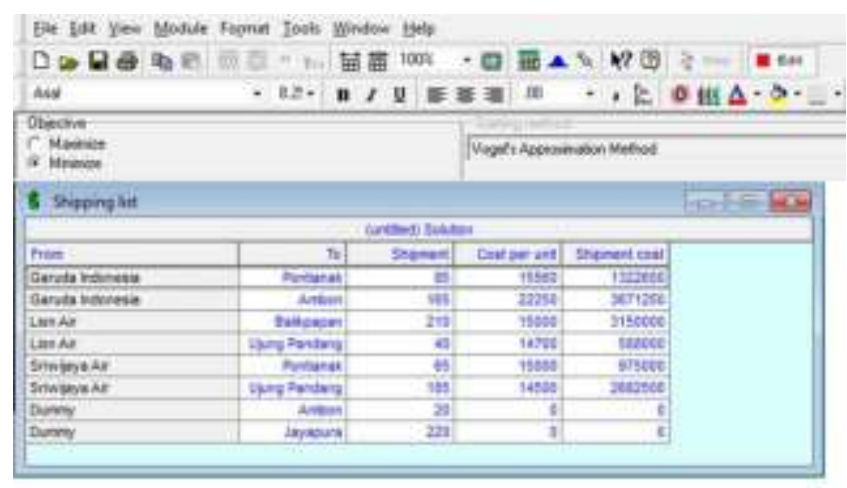

Gambar IV. 3 Rincian Biaya Transportasi Pengiriman Yang Optimal

\section{KESIMPULAN}

Berdasarkan penelitian yang dilakukan oleh penulis dengan mengamati dan menganalisa permasalahan transportasi serta menerapkan model transportasi dan teknik penyelesaian yang berkaitan dengan penelitian maka dapat disimpulkan bahwa :

1. Bagian Pengadaan pada PT. Aviastar Mandiri memiliki metode sendiri untuk proses pengiriman spare part pesawat ke beberapa daerah tujuan Indonesia bagian Tengah dan bagian Timur. Dengan metode tersebut, perusahaan mengeluarkan biaya pengiriman sebesar Rp.13.000.000,- per bulan dengan berat spare part yang dikirimkan sebanyak 990 Kilogram.

2. Setelah mengimplementasikan model transportasi menggunakan metode Vogel's Approximation Method (VAM), maka disimpulkan bahwa metode ini dapat menghemat biaya pengiriman sebesar Rp. $610.650,-$ per bulannya atau sekitar 4,69\%.

3. Aplikasi POM-QM For Windows 3 ini merupakan tools yang dapat digunakan untuk mencari solusi dari bentuk masalah transportasi. Terbukti pada penelitian ini bahwa hasil dari teknik penyelesain perhitungan manual dengan metode Vogel's Approximation Method (VAM) menghasilkan total anggaran transportasi optimal yang sama. Disamping itu juga aplikasi ini sangat membantu sekali dalam mendapatkan informasi yang cepat, tepat dan akurat.

\section{REFERENSI}

Amaliyah, B., Krisdanto, A., \& Perwita, A. (2016). Metode MAX MIN Vogel's Approximation Method Untuk Menemukan Biaya Minimal Pada Permasalahan Transportasi. Seminar Nasional Manajemen Teknologi XXIV (pp. A2-1 - A-2-8). Surabaya: ITS Surabaya.

Ariwibowo, A. (2008). Visualisasi Teori Optimalisasi Biaya Transportasi Untuk Pembelajaran Riset Operasi. Seminar Nasional Informatika (p. 76). Yogyakarta: Seminar Nasional Informatika.

Martini. (2017). Optimasi Pendistribusian Makanan Ringan Pada Algoritma Transportasi Menggunakan Metode Voge. Jurnal Teknik Komputer AMIK BSI Vol. 1, 80.

Muhardi. (2011). Manajemen Operasi Suatu Pendekatan Kuantitatif Untuk Pengambilan Keputusan. Bandung: PT. Refika Aditama.

Siregar, M. (2012). Beberapa Masalah Ekonomi dan Manajemen Transportasi. Jakarta: Lembaga Penerbit Fakultas Ekonomi Universitas Indonesia.

Siswanto. (2007). Operations Research. Jakarta: Erlangga.

Suharsaputra, U. (2014). Metode Penelitian Kuantitatif, Kualitatif dan Tindakan. Bandung: PT. Refika Aditama.

Sujarweni, V. (2014). Metodologi Penelitian. Yogyakarta: PT. Pustaka Baru Press. 